\title{
1 DIATOM THANATOCOENOSIS IN A MIDDLE GALICIAN RÍA: \\ 2 SPATIAL PATTERNS AND THEIR RELATIONSHIP TO THE 3 SEASONAL DIATOM CYCLE IN THE WATER COLUMN AND 4 HYDROGRAPHIC CONDITIONS
}

\author{
Patricia Bernárdez ${ }^{1,2, *}$, Ricardo Prego ${ }^{2}$, Manuel Varela $^{3}$, Guillermo Francés ${ }^{2}$
}

${ }^{1}$ Grupo de Biogeoquímica Marina, Instituto de Investigaciones Marinas (IIM-CSIC).C/ Eduardo Cabello 6, 36208 Vigo, Spain

${ }^{2}$ Departamento de Geociencias Marinas y Ordenación del Territorio, Facultad de Ciencias del Mar, Campus Lagoas-Marcosende s/n. Universidad de Vigo, 36310, Vigo, Spain

${ }^{3}$ Instituto Español de Oceanografía, Centro Costero de A Coruña, Paseo Marítimo Alcalde Francisco Vázquez 10, 15001 A Coruña, Spain

*Corresponding author. Departamento de Oceanografía, Grupo de Biogeoquímica Marina, Instituto de Investigaciones Marinas (IIM-CSIC). C/ Eduardo Cabello 6, 36208 Vigo, Spain. Tel.: +34 986 231930; fax: +34 986292762. E-mail: pbernard@iim.csic.es

Abstract. Modern diatom distribution patterns in the surface sediment of the Ferrol Ría and their relationship to the hydrography and diatom patterns in the water column were studied to determine the hydrographic influence on the record of these biogenic components. Diatom abundance in the water column was assessed for different oceanographic periods and compared with the biosiliceous sedimentary record. Very low abundances were found in the water column during the winter, whereas in spring and summer diatoms proliferated. Chaetoceros spp. formed the bulk of the water column community during spring and summer, followed by Thalassionema nitzschioides and Rhizosolenia spp. Nitzschia longissima represented a significant portion of the winter assemblage, together with Paralia sulcata and benthic taxa. Leptocylindrus danicus, $N$. Iongissima and Skeletonema costatum characterized the autumn campaign, when stratification of the waters occurs, with Leptocylindrus danicus being especially abundant in the outer ría.

Seasonal hydrographic and associated productivity patterns govern the abundance and assemblage of the diatoms preserved in surface sediments. Samples located in the inner ría area and its margins exhibited the highest abundances of diatoms, and were primarily dominated by benthic species. The freshwater group, crysophycean cysts and phytoliths were present in the landward stations influenced by river runoff. The middle ría was characterized by $P$. sulcata, and Thalassiosira spp., with minor occurrences of the benthic and freshwater group. Chaetoceros R.S., L. danicus R.S. and T. nitzschioides typified the outer ría, an assemblage that corresponds to nutrient-rich coastal areas of high productivity influenced by oceanic waters, demonstrating the impact of oceanic waters flowing into the embayment due to enhanced tidal mixing through the narrow channel. Therefore, sediment diatom assemblages reflect diatom production patterns in the water column of the Ría. However, we must proceed with caution when interpreting the paleorecord in the inner area due to the high contribution of allochthonous taxa, which is indicative of low water depths. This paper contributes to a better understanding of diatom thanatocoenosis in the Galician Rías, where very few studies of this kind have been done to date.

Keywords: diatoms, surface sediments, water column, ría, Ferrol, Galicia 


\section{1. Introduction and objectives}

3 The Ría systems, i.e. small coastal embayments that characterize the Galician coast,

4 are fertilized by two sources of nutrients, upwelling and continental runoff (Prego et al., 5 1999a). In addition, rías are characterized by changing hydrographic conditions, salinity 6 gradients, stratification and the mixing of waters.

7 Much of the primary production of these nutrient-replete areas is carried out by diatoms 8 (Nelson et al., 1995) resulting in significant settling fluxes of these biosiliceous 9 organisms. Diatoms are one of the most common microfossils in the sediments 10 underlying coastal upwelling areas (Schuette and Schrader, 1981a, b; Abrantes, 1988; 11 Bao et al., 1997; Bárcena and Abrantes, 1998; Abrantes and Moita, 1999; Nave et al., 12 2001; Romero and Hebblen, 2003; Lopes et al., 2006). The abundance of diatom 13 species in the water column and sediments shows definite regional distribution patterns 14 associated with oceanographic conditions (Pokras and Molfino, 1986; Abrantes and 15 Moita, 1999). Since biogenic silica is severely affected by dissolution in the 16 undersaturated ocean water (Nelson et al., 1995, Ragueneau et al., 2000), a 17 clarification of the connection between the seasonal and spatial variations in assemblages of biosilicate organisms in the water column and those found in the sediment is especially important (Sancetta and Calvert, 1988; Romero et al., 2000; Koning et al., 2001; Abrantes et al., 2002; Bárcena et al., 2004). A combined analysis of the diatom abundance and assemblage composition found in surface sediments and the water column provides an opportunity to help unravel the question of how diatoms are incorporated into seafloor sediments and how modern environmental conditions are reflected therein (van Iperen et al., 1987). Understanding these processes is very important in coastal regions with marked hydrographic gradients and where freshwater and marine conditions alternate, such as in rías and estuaries. Moreover, coastal and small embayment areas are key zones for paleoclimate reconstructions.

29 A large number of papers dealing with diatom thanatocoenosis distribution patterns in 30 the surface sediment have been carried out in continental shelf sediments, on the continental slope and in deep sea upwelling-influenced areas (Schuette and Schrader, 32 1981a, b; Pokras and Molfino, 1986; van Iperen et al., 1987; Abrantes, 1988; Bao et 33 al., 1997; De Sève, 1999; Bao et al., 2000; Jiang et al., 2001; Nave et al., 2001; 34 Romero and Hebblen, 2003; Jiang et al., 2004; Armand et al., 2005; Crosta et al., 35 2005; Romero et al., 2005; Lopes et al., 2006). However, there is a lack of information 
1 on these hydrographic indicators from coastal and estuarine systems and ría 2 environments (Prego et al., 1995, Lapointe et al., 2000; McQuoid, 2002; Hay et al., 3 2003, McQuoid and Nordberg, 2003). Moreover, very little information concerning the 4 seasonal succession of the diatom community and related production patterns has 5 been published on the Galician Rías, in particular the Middle Rías and Rías Altas 6 (Bode and Varela, 1998a, b, Casas et al., 1999; Varela et al., 2001; Varela and Prego, 7 2003; Varela et al., 2005; Bode et al., 2005a, b). In general, these studies have 8 focused on the effect of upwelling and river-derived nutrients on phytoplankton 9 production and their ecology. Therefore, in order to improve our knowledge on these 10 questions, our first objective was to quantify the abundance of these biosiliceous 11 components and how diatoms are incorporated on the seabed, as well as to document 12 their regional distribution patterns. On the basis of this information, the second 13 objective was to relate the abundance and distribution of diatoms in the sediments to 14 the seasonal diatom community in the water column and the main oceanographic ría conditions.

\section{Study area}

The Ferrol Ría is one of the eight small embayments belonging to the Galician Middle Rías located between Cape Ortegal and Cape Finisterre. It therefore provides a representative contrast to the four large rías situated to the south of Cape Finisterre (Western Rías) in terms of morphology, physical oceanography, river contributions and primary production dynamics (Torre Enciso, 1958; Rio and Rodriguez, 1992; Castaing and Guilcher, 1995; Prego et al., 1997; Prego et al., 1999a; Varela et al., 2005). On a plan view it is funnel-shaped, covering an area of $27 \mathrm{~km}^{2}$ with a longitudinal axis $15 \mathrm{~km}$ in length and a maximum width of $\sim 3 \mathrm{~km}$. Depth varies from $32 \mathrm{~m}$ at the mouth to a few meters at the innermost part (Figure 1). From a physiographic point of view, the Ferrol Ría can be divided into different zones (Figure 1):

(1) The innermost zone, characterized by wide mudflats in a very shallow environment.

This area extends from As Pias Bridge to the ría head. The exchange of water and organic material between the mid and inner zone is reduced by this structure (deCastro et al., 2004). Freshwater runoff is mainly supplied by the two principal rivers located at the innermost part, the Grande de Xubia and 
Belelle Rivers. Average river flow volumes are 6 and $0.8 \mathrm{~m}^{3} \mathrm{~s}^{-1}$ respectively (Rio and Rodríguez, 1992; deCastro et al., 2004). The annual river discharge versus the total volume of the ría is 0.8 (deCastro et al., 2004).

(2) The middle zone, extending from As Pias Bridge longitude to the beginning of the Ferrol strait covers most of the ría area;

(3) The outermost area extends from the mouth to the narrow channel, i.e. the Ferrol Strait, which is $2 \mathrm{~km}$ long, $0.35 \mathrm{~km}$ wide and $20 \mathrm{~m}$ in depth. The water exchange between the ría and the shelf occurs through this channel.

The hydrographic behaviour of this ría differs from that of other Western Rías. Here the water circulation, which is strongly dependent upon the tide, may be considered periodic, since river inflow is very low (deCastro et al., 2003). The occasional occurrence of wind-induced currents is another factor controlling residual circulation in the ría, but it only affects near the surface (deCastro et al., 2003). A well-mixed water column is found at the mouth, where high velocity tides enhance mixing. In contrast, the middle and inner parts of the Ferrol Ría seem to be partially stratified during the wet season (deCastro et al., 2004). The intrusion of nutrient-rich water (ENACW) from the shelf is hard due to the orientation of the ría and the narrow shape of the channel (Bode et al., 2005a). The topographic features of the Artabro Gulf cast a shadow on the ría which limits the exchange of ría-shelf water leaving it virtually isolated from upwelled seawater (Prego and Bao, 1997; Prego and Varela, 1998; Prego et al., 1999b).

From a geological standpoint, watersheds are formed by igneous rocks, dominated by schists, gneisses and granites. The sediment contained in the ría basin is of continental and marine origin, derived from the biological activity in these waters and the riverine discharge supply. The type and grain size of the sediment varies throughout the ría (Figure 1, Cobelo-García and Prego, 2004) and depends on the hydrography and velocity of the currents. At the mouth and in the main channel of the ría, the sediments are predominantly made up of fine sand, with a low content of organic matter (1.7-2.5 wt.\%). Conversely, the sediments located in the inner and middle parts of the ría are composed of muddy fractions and higher concentrations of organic matter (3.7-13.2 wt.\%).

\section{Materials and Methods}




\section{3.1. Water column sampling and processing}

2

3 Four seasonal cruises were carried out in the Ferrol Ría onboard the R/V Lura in 2000

$422^{\text {nd }}$ February, $16^{\text {th }}$ May, $11^{\text {th }}$ July and $5^{\text {th }}$ September (Figure 2), covering three different 5 zones of the ría (Figure 1). Water samples were collected using 5 litre 'General 6 Oceanics' Niskin bottles at Stations O, C and M (Figure 1).

7 Samples collected from these stations were preserved in a Lugol's solution and 8 assemblages composition determined using a Nikon microscope, following the 9 technique described by Uthermöhl (1958). A magnification of 100× was used for large forms, $250 \times$ for intermediate and $400 \times$ and $1000 \times$ for small species.

\subsection{Surface sediment sampling and analytical procedures}

Surface sediment samples were taken at 35 sites from the R/V Mytilus (Figure 1 and Table 1). Two different sizes of Van Veen grab samplers were used. Only the surface layer of the sediment was collected $(<1-\mathrm{cm})$ with polyethylene spatulas. The samples were stored at $4^{\circ} \mathrm{C}$ and later oven-dried at $<50^{\circ} \mathrm{C}$.

Opal content in the surface sediments was determined following the method of alkaline digestion by Mortlock and Froelich (1989) optimized to the sediment of rías, as devised by Bernárdez et al. (2005). The subsequent analysis of the dissolved silicate in the extract obtained was carried out using the method reported by Hansen and Grasshoff (1983). Total organic carbon (TOC) was determined by calculating the difference between the total carbon (TC) measured in a Perkin Elmer elemental $\mathrm{CNH}$ analyzer and the total inorganic carbon (TIC) analyzed by calcination loss at temperatures ranging from 550 to $975^{\circ} \mathrm{C}$. Total organic nitrogen (TON) was also determined with the same equipment at the University of Coruña. Data are presented in Cobelo-García and Prego (2004) (Table 1, Figure 3).

The sediment samples were prepared for diatom count according to the technique described by Abrantes et al. (2005). To prepare the slides, a known volume of solution, previously stirred for homogenization (Battarbee, 1973), was spread evenly onto two clean circular cover slips placed in a circular evaporation tray. After the dishes were dried, the smear slides were removed and assembled with Permount ${ }^{\mathrm{TM}}$ mounting medium onto permanently labelled slides. 


\section{3.3. Taxonomic identification}

2

3 The identification of diatoms found in the water column was based on a variety of 4 taxonomic monographs, but mainly the work of Hasle and Syvertsen (1996). Total 5 abundance is expressed as cells $\mathrm{ml}^{-1}$ and the relative percentage of each species and 6 ecological group was also calculated.

7 Our taxonomic identification (genera and species) of the diatoms found in the surface 8 sediments is based mainly on ecological characteristics using several floral, keys and 9 specific bibliography (Taxonomic appendix). Schrader and Gersonde's (1978) 10 guidelines were followed for diatom counts and total number estimates. Hence, only 11 diatoms that were essentially complete were counted. At least 300 diatom valves were 12 identified in each sample to ensure the proper assessment of diatom abundance. 13 Absolute abundances are expressed in number of valves per gram of dry sediment. In 14 a few cases, difficulties arose in distinguishing between two or more species, so these species were combined into one count group or genus group. Taxa were grouped into three different types: dominant taxa, species of the same genus living in similar environments and species showing a comparable ecology and distribution, i.e. common ecological meanings, such as freshwater and benthic. $P$. sulcata is not included in the benthic assemblage since it is considered to be tychopelagic. The number of diatom fragments, silicoflagellates, sponge spicules, palynomorphs, phytoliths, crysophycean cysts and radiolaria per gram of sediment was also assessed. In addition, we calculated the relative contribution of each biosiliceous component versus their total number per gram of sediment. The distribution of diatoms and siliceous components was plotted using the Golden Software Surfer v. 8.0 package for Windows, according to the Kriging method for data interpolation.

\section{Results}

\subsection{Planktonic diatom composition in the water column}

Phytoplankton abundance was high all year round except in February, when the number of diatoms was very low, $\sim 1000$ times lower than in the other periods (82-122 
1 same sampling date, with the exception of the outer station during the July cruise, 2 when diatom abundance was between six and ten times lower than in the other 3 stations. The highest diatom abundances were sampled in May and September. Only 4 the most representative species found in the water column were plotted in Figure 5.

5 The main component of the diatom assemblage was Chaetoceros spp., whose 6 contribution ranged from 42 to $99 \%$ in May and July. In summer (July cruise) 7 Chaetoceros spp. appeared together with Rhizosolenia spp., Thalassiosira spp. and T. 8 nitzschioides. In contrast, Chaetoceros spp. practically disappeared in February and 9 September.

10 The N. longissima group showed a trend opposite to that of Chaetoceros R.S. This 11 group accounted for the greatest percentage of total diatoms during the February and 12 September cruises, especially in the samples taken from the outermost station. The 13 February campaign was also characterized by the appearance of benthic taxa and the 14 thycopelagic species $P$. sulcata (1.5-3\%) in the water, particularly in stations $\mathrm{O}$ and $\mathrm{C}$.

15 L. danicus was the third most important component of the diatom assemblage in the 16 water column. It was absent during all the sampling periods and stations, except for 17 September when it appeared in high abundances. On this cruise, L. danicus accounted 18 for around $75 \%$ of the total diatoms from station $\mathrm{O}$ and $\sim 35 \%$ for sites $\mathrm{C}$ and $\mathrm{M}$.

19 The contribution of $S$. costatum to the diatom community was also relevant during 20 September (3195-12166 cell $\mathrm{ml}^{-1}$ ), with the highest occurrence of this species found in 21 the innermost station (16\%). However, S. costatum was absent in February and May 22 when the riverine discharge was high.

23 Thalassiosira spp. were present in high percentages (39.3\%) and abundance (5299 24 cells $\mathrm{ml}^{-1}$ ) during the July cruise in station M. It is important to note that only the large 25 species of Thalassiosira were included in this group. However, most of the small 26 centric diatoms $(<30 \mu \mathrm{m})$ probably belong to this genus.

$27 T$. nitzschioides showed relative percentage of up to $4.8 \%$ in station $\mathrm{M}$ in July. This 28 species also displayed significant percentages during the February cruise (absolute

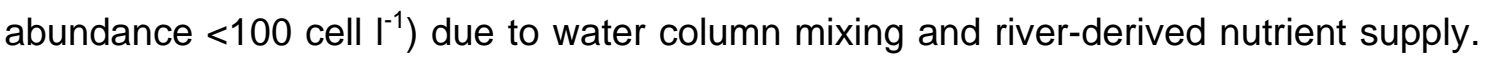

30 It disappeared completely in May and September.

31 Rhizosolenia spp. were found in station O during the July cruise, accounting for $4.5 \%$ 32 of the assemblage.

33 No evidence of freshwater diatoms in the water column was recorded throughout the 34 sampling period. 
1 4.2. Diatom assemblages and biosiliceous material in the surface 2 sediments

4 The diatom signal in surface sediments depict a clear W-E pattern, following the opal 5 content distribution (Cobelo-García and Prego, 2004) (Figure 3, Table 1). The 6 distribution patterns of diatom valves abundance show high generalized values in the 7 inner ría and A Malata Bay $\left(4.2 \times 10^{6}\right.$ valves $\left.\mathrm{g}^{-1}\right)$ (Figure 3). On average, the abundance 8 is $1.1 \times 10^{6}$ valves $\mathrm{g}^{-1}$, which accounted for $30.7 \%$ of the total biosiliceous components 9 found in the sediment. This mean value is representative of the middle ría. Low 10 abundances characterize the channel and outer ría (down to $1.4 \times 10^{6}$ valves $\mathrm{g}^{-1}$ ). At 11 stations located along the middle ría connecting the inner area and the outer-channel 12 zones, diatom concentration is relatively constant and lower than what was found at 13 stations located in the inner areas. The distribution pattern of the diatom fragments is 14 similar to that of complete valves, accounting, on average, for $22.8 \%$ of the sediments total biosiliceous component. Other fragments of diatoms, such as cingulum (diatom girdle bands) are also found in significant abundance (averaging 5.8\% of the BSi) in the middle areas of the ría and along the northern margin (Figure 3).

18 The benthic assemblage dominate the superficial sediment, averaging 55.5\% (range 19 16.4-86.2\%) (Figure 4). The highest values are found in the inner ría as well as in A 20 Malata Bay close to the city of Ferrol. High percentages are recorded all along the margins, whereas low values characterize the main channel and the station located outside the ría.

23 Chaetoceros R.S. is the second more important component to the diatom assemblage, accounting for an average of $23 \%$. In general, the highest values are found in the main channel and outer areas, particularly from station 8 towards the mouth of the ría 26 (Figure 4).

27 P. sulcata account for up to $31.3 \%$ of the association, with a mean percentage of $2811.1 \%$ (Figure 4). Very low percentages are found in the inner ría (0-8\%), backwards 29 As Pías Bridge. This species is prevalent in the middle area on the southern margin 30 ( $20 \%)$, where shallow waters are found, and throughout the outer ría.

31 L. danicus R.S. is found in the sediment in small quantities. Maximum percentages $32(\sim 3.7 \%)$ are observed in the outer and middle ría, and this species is virtually absent 33 from the stations found in the innermost areas (Figure 4).

$34 T$. nitzschioides represent an average of $1.4 \%$ of the total diatom community. Its 35 distribution is irregular throughout the ría (Figure 4). Maximum values $(\sim 5 \%)$ were 
1 located at the outermost stations and in the main channel. It is also found (1-2\%) in

2 some sampling sites close to the Grande de Xubia River in the inner ría area.

3 Other diatom genera such as Thalassiosira spp., S. costatum and Rhizosolenia spp.

4 occasionally appear in the surface sediment. In general, Thalassiosira spp. is present

5 in the middle ría (Figure 4), whereas S. costatum and Rhizosolenia spp. (not shown)

6 are found in very low ( $<2 \%)$ on the margins of the ría and in the outermost station.

7 Freshwater taxa is restricted to the areas receiving the main river flow (up to 13.5\%)

8 (Figure 4). Throughout the rest of the ría, percentages are low, amounting to around

$92 \%$. The distribution of the freshwater group coincided with the important occurrence of

10 other biosiliceous components such as phytoliths and crysophycean cysts, also

11 considered to be run-off tracers (Figure 3). The phytolith content (silica-rods bodies

12 derived from grass) in the ría sediments is relatively high, accounting for $11.5 \%$ of the

13 total biogenic silica. It remain relatively constant in terms of abundance throughout the

14 middle-inner ría, exhibiting a homogeneous distribution, with maximum values of

$159.7 \times 10^{5}$ specimens $\mathrm{g}^{-1}$ in the middle ría and in stations located close to the northern

16 margin while abundance values of less than $2.0 \times 10^{5}$ specimens $\mathrm{g}^{-1}$ are found in the

17 outermost sampling sites and in the central channel. Crysophycean cysts, however,

18 made up a small percentage of the biosiliceous material. Maximum abundances

$19\left(\sim 5 \times 10^{4}\right.$ specimens $\left.\mathrm{g}^{-1}\right)$ are sited at the mouth of the Grande de Xubia River and on the

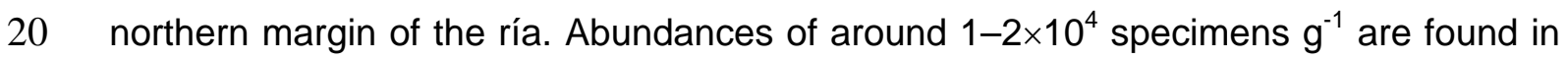

21 the rest of the sampling sites.

22 Other siliceous components in the sediment present a complex geographical 23 distribution (Figure 3). One of the main contributors to biogenic silica are the remains of 24 sponge spicules (averaging 29.9\%). Their abundance was low in the outer area and in 25 some of the innermost stations. High contents are found in the middle zone $\left(2.0 \times 10^{6}\right.$ 26 specimens $\mathrm{g}^{-1}$ ) and in A Malata Bay. Silicoflagellates are present in very low 27 concentrations (maximum value of $2.5 \times 10^{4}$ specimens $\mathrm{g}^{-1}$ ), with a scattered distribution 28 pattern. Quantities of the dinoflagellate Actiniscus pentasterias in the surface 29 sediments are very low (mean $3.3 \times 10^{3}$ specimens $\mathrm{g}^{-1}$ ). This organism appears in the 30 ría sediments in stations located along the northern margin of the outer area and in the 31 main channel.

32 Palinomorphs abundance is low, displaying a patchy distribution with higher values in 33 stations located in the inner-middle areas in the central zone of the longitudinal channel 34 (Figure 3). The maximum value is $3.7 \times 10^{4}$ specimens $\mathrm{g}^{-1}$ from station 53. 


\section{5. Discussion}

4 The abundance of diatom valves in the surface sediments is in accordance with what was recorded in the seabed of the Rías Baixas and from the continental shelf (Prego et al., 1995, Bao et al., 1997). The geographical pattern in diatom distribution is also similar to that of other rías, with maximum values located close to the ría head. In general, diatom assemblages of ría-estuarine environments are characterized by the low percentages of open ocean taxa, in contrast to what has been observed on the 11 1999).

12 On the basis of recent diatom and biosiliceous component distributions, several zones 13 have been recognized:

\subsection{Estuarine domain (Zone 1)}

This zone of the ría extends from the mouths of the Belelle and Grande de Xubia Rivers up to As Pías Bridge. The most representative species in the sediments of this area were the benthic and freshwater groups with small occurrences of $T$. nizschioides and $P$. sulcata. T. nitzschioides also traced the nutrient supply from oceanic waters in the outer station during the summer sampling, but it was diluted by fast-blooming species such as Chaetoceros spp (Figure 5). Hence, the higher contribution of $T$. nitzschioides in the outer ría is indicative of the influx of nutrient-rich offshore shelf waters (Hay et al., 2003). However, their appearance in the water column in the inner ría could be controlled by the input of fluvial-derived nutrients (Pokras and Molfino, 1986; Abrantes, 1988), which reflects this species' adaptation to the innermost areas of estuarine-like systems (Figure 5). In the Ferrol Ría, it has a relatively low contribution to the sediment in the innermost areas, owing to the great abundance of benthic and freshwater taxa, which veils the effectiveness of this species as a tracer of past changes in river discharge.

The high abundance of benthic and freshwater taxa in the inner zone in sediments is typical of small embayments, fjords and estuarine environments with protected inner 33 areas (Hay et al., 2003; Lapointe, 2000; Bernárdez et al., 2006). On the other hand, the 34 high surface area of intertidal environments favours the growth of benthic diatoms in sediments. In this way, this group can be used as a reliable proxy of shallow waters 
1 and intertidal environments, especially in this enclosed and protected environment.

2 Therefore, percentages of up to $60 \%$ found in a marine paleoclimatic record recovered

3 in the ría could be indicative of shallow waters (approximately below $5 \mathrm{~m}$ depth).

4 Besides, the higher amounts of fine sediments and organic carbon (Cobelo-García and

5 Prego, 2004) (Table 1) permit the establishment of reducing conditions that will lead to

6 appropriate settings for diatom conservation.

7 A large number of crysophycean cysts, phytoliths and palinomorphs were also detected

8 in this zone, which would point to the existence of strong riverine influence. Moreover,

9 freshwater diatoms are indicators of sources of continental material and reduced

10 salinity resulting from freshwater drainage from land. In fact, the lithogenic components

11 were more prevalent in this area, reflected by the presence of mud and high Fe levels

12 in the surface sediments (Cobelo-García and Prego, 2004). However, the restricted

13 exchange between the inner ría and the middle areas due to the presence of As Pías

14 Bridge may impede the transport of these taxa. Moreover, strong tidal currents during

15 ebb tide could transport a few specimens in the surface waters to the open ocean.

\subsection{Middle ría (Zone 2)}

19

The area extends from As Pías Bridge to site 10. The sediments in this zone are characterized by a diatom assemblage dominated by $P$. sulcata and Thalassiosira spp. Thalassiosira spp. appeared in the water column in July, and is therefore strongly related to high productivity conditions (Figure 5). However, Thalassiosira spp. also was found in relatively high abundances in the winter season all along the Portuguese coast, as a response to the continuous input of nutrients (Abrantes and Moita, 1999). The spatial distribution of $P$. sulcata in the sediments was similar to that of Chaetoceros R.S., meaning that it is better adapted to the outer and middle areas of the ría where oceanic influence is high. In fact, this species is indicative of the influence of upwelling and high productivity conditions (Lapointe, 2000; Mcquoid and Nordberg, 2003 and references therein).

31 The freshwater and benthic groups ( $\sim 3 \%$ and $\sim 50 \%$ respectively) were also present in 32 the sediments, together with high concentrations of porifera and phytoliths.

33 Therefore, this zone represents a combination of both marine and freshwater 34 influences. In fact, phytoliths are certainly an indication of transport from the inner areas in the low-saline surface layer. The abundance of all of these markers at sites 
1 remote from the river would indicate that this area is influenced both by river discharge 2 and upwelling.

\subsection{Oceanic domain (Zone 3)}

This zone extends from sampling site 10 towards the open sea, covering the outer area and the main channel. Our results show that the surface sediments of this area are characterized by Chaetoceros R.S., L. danicus R.S. and T. nitzschioides. In the water column, Rhizosolenia spp. were typical of the summer blooms in the outer ría zone, but disappear with the appearance of Chaetoceros spp. taxa.

Chaetoceros spp. was representative of the spring and summer blooms (Figure 5), when primary productivity is enhanced by the nutrient input of oceanic waters and solar irradiance. In the case of the Ferrol Ría, the input of nutrient-rich central waters (ENACW) was low during the study period, even when upwelling was well developed in the Galician shelf area. In fact, the upwelling of shelf water only affected the water layer below $15 \mathrm{~m}$ in the outer ría during summer (Varela et al., 2003). Downcore concentrations of Chaetoceros spp. R.S. would accurately reflect episodes of high spring and summertime productivity.

The sediment distribution of $L$. danicus in this area reflects its proliferation in the water column in September, in that it only appeared in the outer stations (Figure 5). Oceanographic patterns during the September cruise were characterized by reduced runoff and the absence of northerly winds, which would point to the stratification of the water column (Figure 2). A thin layer of nutrient-rich shelf water entered the ría through the bottom, provoking the blooming of this fast-growing competitor, L. danicus (Bode et al., 2005b). Ecologically, it represents the input of nutrient-rich shelf waters and water column stratification. Therefore, as reported by Bárcena et al., (2001), this species may be used in the sedimentary record as an indicator of the late upwelling period and beginning of stratification.

S. costatum, which appears mostly in the middle station in September, can be used as indicative of late summer blooms, (Figure 5). In the Rías Baixas (Tilstone et al., 2000; Varela et al., 2005) and A Coruña Bay (Varela and Prego, 2003), its occurrence is linked to high nutrient concentrations. However, ecologically, S. costatum is linked to the supply of nutrients from riverine discharge since it appears occurs in association with low salinities (Varela et al., 2005) and the nutrient-enrichment of the rías in winter caused by the high freshwater input (Casas et al., 1999; Rodríguez et al., 2003; 
1 deCastro et al., 2006; Prego et al., 2007). This species was found in low percentages

$2(<2 \%)$ in the sediments of this area (not shown).

3 Therefore, the water column diatom assemblage and sediment record of this area is

4 mainly determined by marine influence. However, A Malata Bay, while located in the

5 outer ría, presents characteristics that are typical of the inner areas, with high

6 percentages of benthic assemblages, as well as elevated concentrations of

7 crysophycean cysts and phytoliths. This zone is affected by the harbour area, and it is

8 relatively well-protected from the inflow of marine waters and the mixing of the water

9 column through the channel.

10 The main channel and the outer station also make an important contribution to the 11 benthic assemblage ( $20 \%)$, due to transport from the innermost areas as a result of 12 the strong tidal influence and low residence time of the waters in the ría (deCastro et 13 al., 2003; deCastro et al., 2004).

\subsection{Thanatocoenosis-biocoenosis links}

Diatom percentages found in the water column and in the sediment were compared, using the average percentages of each species for all sampling campaigns and their relative concentration in the underlying sediment (Middle-St 11, Channel-St 7, Outer-St 42, Figure 6).

The sediment assemblage differs from its pelagic counterpart in the middle-inner areas, where benthic and freshwater assemblages dominate. In this area, all the species showed a reduced relative contribution, due to the high abundance of the benthic taxa. $P$. sulcata. And T. nitzschioides showed higher percentages in the sediment than in the water column in stations $\mathrm{C}$ and $\mathrm{O}$. Their abundance and corrosion resistant valves would justify their use as a paleoceanographic proxy (Tanimura, 1999). Similarly, $T$. nitzschioides was also found in greater abundance in the sediment trap material in the 28 Pontevedra Ría (Varela et al., 2004).

The relative contribution of Chaetoceros R.S. in the sedimentary record is always overestimated due to their high resistance. The contribution of this group to the seabed in the main channel and outer ría was slightly higher than in the water column. An interesting point for paleoreconstructions is that when this species is found in percentages lower than ca. $20 \%$ we may conclude that the sediment corresponds to 34 the innermost areas of the ría, assuming that hydrographic conditions do not change with time. 
1 A pattern common to all sampling stations is the absence of $N$. longissima in the 2 sediments. Winter conditions, (reduced light and mixing of waters), were characterized 3 by the presence of $N$. longissima in surface waters (Figure 5), as observed in other rías 4 (Prego et al., 2007). This species could be a good indicator of the winter conditions in 5 the ría, but dissolution of this species has removed this signal from recent sediments. 6 In this sense, the appearece of $N$. longissima in sediments would be indicative of good 7 preservation conditions. Moreover, the presence of low silicified species such as $S$. 8 costatum and Rhizosolenia spp. (not shown) in the sediments is very low (under $2 \%$ ), 9 which also prevents their use as environmental tracers. As reported in the case of $N$. 10 longissima, their occurrence would reflect both adequate oceanographic conditions for 11 growth and high preservation efficiency in the sediments.

12 In brief, many processes, such as differential dissolution, lateral advection and 13 transport, in addition to hydrographic conditions, complicate the relationship between 14 the living diatom assemblage and the one found in the underlying sediments. In this 15 way, inferences regarding paleoenvironmental conditions must be based on several 16 diatom species together with other proxies e.g. geochemical, sedimentological and 17 biological. The next step in this study will attempt to generate a paleoecological transfer 18 function to characterize the relationships between modern diatom assemblages and 19 the hydrographic conditions of the Ferrol Ría.

\section{6. Conclusions}

Water column diatom community production patterns followed hydrographical changes throughout the sampling period. Abundance was variable depending on location and season, and linked to runoff supply, water dynamics and circulation within the ría. Diatom production was high, except during the winter season, due to the low residence time of ría waters and the constant input of river-derived nutrients. Chaetoceros spp. was dominant in spring and summer in the water column, together with $T$. nitzschioides and Rhizosolenia spp. $N$. longissima, $P$. sulcata and benthic taxa characterized winter season, whereas $L$. danicus was abundant in autumn.

31 The distribution pattern of diatoms in surface sediments reflects hydrographic conditions and water column productivity. The sedimentary diatom assemblage is composed of the most solution-resistant of the species found in the water column. The dominant diatom species in the sedimentary assemblage are those associated with the benthic environment and with spring and summer blooming conditions. Assemblage 
1 composition allows a differentiation to be made between oceanic-influenced sediments

2 and those in the inner-ría. Diatoms are abundant in the inner sediments of the ría,

3 influenced by freshwater runoff and low depths, which favors the proliferation of benthic

4 diatom assemblage. The transition from the stations affected by oceanic waters to the

5 ones located in the inner area can be detected in the middle ría. Diatoms are in low

6 abundance in outer ría sediments, where planktonic diatoms make up the dominant

7 assemblage. Hence, paleoceanographic reconstructions based on sediment cores from

8 the inner ría would provide detailed records of fluctuations in ría environments and sea

9 level changes, whereas cores recovered in the outer ría would yield more information

10 on general patterns of coastal upwelling generated primary production.

11 Chaetoceros R.S. and L. danicus R.S. may be used as indicators of the oceanic waters

12 flowing into the ría. L. danicus R.S. also tracks the stratification conditions of the water

13 column with reduced upwelling. $N$. longissima, if found in the sediments, is

14 representative of winter conditions and a well mixed water column. $T$. nizschioides is

15 linked to high production conditions during summer and the nutrient supply from

16 oceanic waters. However, it also points to the occurrence of nutrient-enrichment from

17 continental waters, but it is better preserved in the sediments of the outer areas. These

18 observations can be used for future paleoenvironmental reconstructions of the coastal

19 changes and the spatial and -temporal evolution of ría environments. 
1 Acknowledgments. This work was supported by FEDER-CICYT under the project 2 'Biogeochemical Processes in the Ferrol Ría: Fertilization by Nutrients and Spatio3 temporal Variation of Metals in the Sediment', ref. 1FD97-0479-C03-02. We are indebted to the crew of the R/V Lura and R/V Mytilus that greatly facilitated sampling and field work, and also to the technicians who participate in all the phases of the laboratory work. Two anonymous reviewers are sincerely acknowledged for helping us to improve the manuscript. Patricia Bernárdez thanks the Spanish Government (FPU program) and Xunta de Galicia for financial support.

\section{References}

Abrantes, F., 1988. Diatom assemblages as upwelling indicators in surface sediments in Portugal. Marine Geology 85, 15-39.

Abrantes, F., Gil, I., Lopes, C., Castro, M., 2005. Quantitative diatom analyses-a faster cleaning procedure. Deep-Sea Research I 52, 189-198.

Abrantes, F., Moita, T., 1999. Water column and recent sediment data on diatoms and coccolithophorids, off Portugal, confirm sediment record of upwelling events. Oceanologica Acta 22, 319-336.

Abrantes, F., Meggers, H., Nave, S., Bollman J., Palma, S., Sprengel, C., Henderiks, J., Spies, A., Salgueiro, E., Moita, T., Neuer, S., 2002. Fluxes of micro-organisms along a productivity gradient in the Canary Islands region $\left(29^{\circ} \mathrm{N}\right)$ : implications for paleoreconstructions. Deep-Sea Research II 49, 3599-3629.

Armand, K.L., Crosta, X., Romero, O., Pichon, J.-J., 2005. The biogeography of major diatom taxa in Southern Ocean sediments: 1 . Sea ice related species. Palaeogeography, Palaeoclimatology, Palaeoecology 223, 93-126.

Bao, R., Varela, M., Prego, R., 1997. Mesoscale distribution patterns of diatoms in surface sediments as tracers of coastal upwelling of the Galician shelf (NW Iberian Peninsula). Marine Geology 144, 117-130.

Bao, R., De Stigter, H., van Veering, T.C.E., 2000. Diatom fluxes in surface sediments of Goban Spur continental margin, NE Atlantic Ocean. Journal of Micropaleontology 19, 123-131.

Bárcena, M.A., Abrantes, F., 1998. Evidence of a high productivity area off the coast of Malaga from studies on surface sediments. Marine Micropaleontology 35, 91-103.

Bárcena, M.A., Cacho, I., Abrantes, F., Sierro, F.J., Grimalt, J., Flores, J.A., 2001. Paleoproductivity variations related to climatic conditions in the Alboran Sea (Western Mediterranean) during the last Glacial-Interglacial transition: the diatom record. Palaeogeography, Palaeoclimatology, Palaeoecology 167, 337-357.

Bárcena, M.A., Flores, J.A., Sierro, F.J., Pérez-Folgado, M., Fabres, J., Calafat, A., Canals, M., 2004. Planktonic response to main oceanographic changes in the Alboran Sea (Western Mediterranean) as documented in sediment traps and surface sediments. Marine Micropaleontology 53, 375-398.

Battarbee, R., 1973. A new method for estimating absolute microfossil numbers with special reference to diatoms. Limnology and Oceanography 18, 647-653.

Bernárdez, P., Prego, R., Francés, G., González-Álvarez, R., 2005. Opal content in the Ría de Vigo and Galician continental shelf: biogenic silica in the muddy fraction as an accurate paleoproductivity proxy. Continental Shelf Research 25, 1249-1264. 
Bernárdez, P., Francés, G., Prego, R., 2006. Benthic-pelagic coupling and postdepositional processes as revealed by the distribution of opal in sediments: The case of the Ría de Vigo (NW Iberian Peninsula). Estuarine, Coastal and Shelf Science 68, 271-281.

Bode, A., Varela, M., 1998a. Primary production and phytoplankton in three Galician Rías Altas (NW Spain): seasonal and spatial variability. Scientia Marina 62, 319-330.

Bode, A., Varela, M, 1998b. Mesoscale estimations of primary production in shelf waters: a case study in the Golfo Artabro (NW Spain). Journal of Experimental Marine Biology and Ecology 229, 111-131.

Bode, A., González, N., Rodríguez, C., Varela, M., Varela, M.M., 2005a. Seasonal variability of plankton blooms in the Ria de Ferrol (NW Spain): I. Nutrient concentrations and nitrogen uptake rates. Estuarine, Coastal and Shelf Science 63, 269-284.

Bode, A., Álvarez-Ossorio, M.T., González, N., Lorenzo, J., Rodríguez, C., Varela, M., Varela, M.M., 2005b. Seasonal variability of plankton blooms in the Ria de Ferrol (NW Spain): II. Plankton abundance, composition and biomass. Estuarine, Coastal and Shelf Science 63, 285-300.

Casas, B., Varela, M., Bode, A., 1999. Seasonal succession of phytoplankton species on the coast of A Coruña (Galicia, Northwest Spain). Boletín del Instituto Español de Oceanografía 15, 413-429.

Castaing, P., Guilcher, A., 1995. Geomorphology and sedimentology of rias. In: Perillo, G.M.E. (Ed.), Geomorphology and sedimentology of estuaries. Developments in sedimentology 53. Elsevier Science, Amsterdam, pp. 69-111.

Cobelo-Garcia, A., Prego, R., 2004. Influence of point sources on trace metal contamination and distribution in a semi-enclosed industrial embayment: The Ferrol Ria (NW Spain). Estuarine, Coastal and Shelf Science 60, 695-703.

Crosta, X., Romero, O., Armand, L.K., Pichon, J.-J., 2005. The biogeography of major diatom taxa in Southern Ocean sediments: 2. Open ocean related species. Palaeogeography, Palaeoclimatology, Palaeoecology 223, 66-92.

deCastro, M., Gómez-Gesteira, M., Prego, R., Neves, R., 2003. Wind influence on the water exchange between the Ria of Ferrol (NW Spain) and the shelf. Estuarine, Coastal and Shelf Science 56, 1055-1064.

deCastro, M., Gomez-Gesteira, M., Prego, R., Alvarez, I., 2004. Ria-ocean exchange driven by tides in the Ria of Ferrol (NW Spain). Estuarine, Coastal and Shelf Science 61, 15-24.

deCastro, M., Álvarez, I., Varela, M., Prego, R., Gómez-Gesteira, M., 2006. Miño River dams discharge on neighbour Galician Rias Baixas (NW Iberian Peninsula): Hydrological, chemical and biological changes in water column. Estuarine, Coastal and Shelf Science $70,52-62$.

De Sève, M.A., 1999. Transfer function between surface sediment diatom assemblages and sea-surface temperature and salinity of the Labrador Sea. Marine Micropaleontology 36, 249-267.

Hansen, H.P., Grashoff, K., 1983. Automated chemical analysis. In: Grashoff, M., Ehrhardt, M., Kremlin, K. (Eds.), Methods of Seawater Analysis. Verlag Chemie, Weinheim, pp. 368376.

Hasle, GR., Syvertsen, E.E., 1996. Marine Diatoms. In: Tomas, C.R., Hasle, G.R., Syvertsen, E.E., Steidinger, K.A., Tangen, K., (Eds.), Identifying Marine Diatoms and Dinoflagellates. Academic Press, New York, pp. 5-385.

Hay, M.B., Pienitz, R., Thomson, R.E., 2003. Distribution of diatom surface sediment assemblages within Effingham Inlet, a temperate fjord on the west coast of Vancouver Island (Canada). Marine Micropaleontology 48, 291-320.

Jiang, H., Zheng, Y., Ran, L., Seidenkrantz, M.S., 2004. Diatoms from the surface sediments of the South China Sea and their relationships to modern hydrography. Marine Micropaleontology 53, 279-292. 
Jiang, H., Seidenkrantz, M.-S., Knudsen, K.L., Eiríksson, J., 2001. Diatom surface sediment assemblages around Iceland and their relationships to oceanic environmental variables. Marine Micropaleontology 41, 73-96.

Koning, E., van Iperen, J.M., van Raaphorst, W., Helder, W., Brummer, G.-J.A., van Weering, T.C.E., 2001. Selective preservation of upwelling-indicating diatoms in sediments off Somalia, NW Indian Ocean. Deep-Sea Research 48, 2473-2495.

Lapointe, M., 2000. Modern diatom assemblages in surface sediments from the Maritime Estuary and the Gulf of St. Lawrence, Québec (Canada). Marine Micropaleontology 40, 43-65

Lopes, C., Mix, A.C., Abrantes, F., 2006. Diatoms in northeast Pacific surface sediments as paleoceanographic proxies. Marine Micropaleontology 60, 45-65.

McQuoid, M.R., 2002. Pelagic and benthic environmental controls on the spatial distribution of a viable diatom propagule bank on the Swedish west coast. Journal of Phycology 38, 881-893.

McQuoid, M.R., Nordberg K., 2003. The diatom Paralia sulcata as an environmental indicator species in coastal sediments. Estuarine, Coastal and Shelf Science 56, 339-354.

Mortlock, R.A., Froelich, P., 1989. A simple method for the rapid determination of biogenic opal in pelagic marine sediments. Deep-Sea Research 36, 1415-1426.

Nave, S., Freitas, P., Abrantes, F., 2001. Coastal upwelling in the Canary Island region: spatial variability reflected by the surface sediment diatom record. Marine Micropaleontology 42, 1-23.

Nelson, D.M., Tréguer, P., Brzezinski, M.A., Leynaert, A., Quéquiner, B., 1995. Production and dissolution of biogenic silica in the ocean: revised global estimates, comparison with regional data and relationship to biogenic sedimentation. Global Biogeochemical Cycles 9, 359-372.

Pokras, E.M., Molfino, B., 1986. Oceanographic control of diatom abundances and species distributions in surface sediments of the tropical and southeast Atlantic. Marine Micropaleontology 10, 165-188.

Prego, R., Bao, R., 1997. Upwelling influence on the Galician coast: Silicate in shelf water and underlying surface sediments. Continental Shelf Research 17, 307-318.

Prego, R., Varela, M., 1998. Hydrography of the Artabro Gulf in summer: western coastal limit of Cantabrian seawater and wind-induced upwelling at Prior Cape. Oceanologica Acta 21, 145-155.

Prego, R., Bao, R., Howland, R., 1995. The biogeochemical cycling of dissolved silicate in a Galician Ría. Ophelia 42, 301-318.

Prego, R., Barciela, M.C., Varela, M., 1999a. Nutrient dynamics in the Galician coastal area (Northwestern Iberian Peninsula): Do the Rias Bajas receive more nutrient salts than the Rias Altas? Continental Shelf Research 19, 317-334.

Prego, R., Varela, M., Bode, A., Canle, M., Lorenzo, J., Carballo, R., 1999b. Oceanography of the Gulf of Artabro (northwestern Iberian Peninsula) in early spring: General patterns. Boletín del Instituto Español de Oceanografía 15, 73-79.

Prego, R., Guzmán-Zuñiga, D., Varela, M., deCastro, M., Gómez-Gesteira, M., 2007. Consequences of winter upwelling events on biogeochemical and phytoplankton patterns in a western Galician ria (NW Iberian peninsula). Estuarine, Costal and shelf Science 73, 409-422.

Ragueneau, O., Tréguer, P., Leynaert, A., Anderson, R.F., Brzezinski, M.A., DeMaster, D.J., Dugdale, R.C., Dymond, J., Fischer, G., François, R., Heinze, C., Maier-Reimer, E., Martin-Jézéquel, V., Nelson, D.M., Quéquiner, B., 2000. A review of the Si cycle in the modern ocean: Recent progress and missing gaps in the application of biogenic opal as a paleoproductivity proxy. Global and Planetary Change 26, 317-365.

Rio, F.X., Rodríguez, F., 1992. Os Rios Galegos: Morfoloxía e Réxime. Consello da Cultura Galega, Santiago de Compostela, $319 \mathrm{pp}$. 

assemblages and pigment composition at a fixed station of the Ría of Pontevedra (NW Spain). Estuarine, Coastal and Shelf Science 58, 499-515.

Romero, O.E., Hebbeln, D., 2003. Biogenic silica and diatom thanatocoenosis in surface sediments below the Peru-Chile Current: controlling mechanisms and relationship with productivity of surface waters. Marine Micropaleontology 48, 71-90.

Romero, O.E., Fischer, G., Lange, C.B., Wefer, G, 2000. Siliceous phytoplankton of the western equatorial Atlantic: sediment traps and surface sediments. Deep-Sea Research II 47, 1939-1959.

Romero, O.E., Armand, L.K., Crosta, X., Pichon, J.-J., 2005. The biogeography of major diatom taxa in Southern Ocean sediments: 3. Tropical/Subtropical species. Palaeogeography, Palaeoclimatology, Palaeoecology 223, 49-65.

Sancetta, C., Calvert, S.E., 1988. The annual cycle of sedimentation in Saanich Inlet, British Columbia: implications for the interpretation of diatom fossil assemblages. Deep-Sea Research 35, 71-90.

Schrader, H., Gersonde, R., 1978. Diatoms and silicoflagellates. Utretch Micropaleontological Bulletins 17, 129-176.

Schuette, G., Schrader, H., 1981a. Diatom taphocoenosis in the coastal upwelling area off south west Africa. Marine Micropaleontology 6, 131-155.

Schuette, G., Schrader, H., 1981b. Diatoms in surface sediments: A reflection of coastal upwelling. In: Richards, F., (Ed.), Coastal Upwelling, Coastal and Estuarine Sciences, American Geophysical Union, Washington DC, pp. 372-380

Tanimura, Y., 1999. Varieties of a single cosmopolitan diatom species associated with surface water masses in the North Pacific. Marine Micropaleontology 37, 199-218.

Tilstone, G.H., Míguez, B.M., Figueiras, F.G., Fermín, E.G., 2000. Diatom dynamics in a coastal ecosystem affected by upwelling: Coupling between species succession, circulation and biogeochemical processes. Marine Ecology Progress Series 205, 23-41.

Torre Enciso, E., 1958. Estado actual del conocimiento de las Rias Gallegas. In: Homenaxe a Otero Pedrayo. Editorial Galaxia, Vigo, pp. 237-250.

Uthermöhl, H, 1958. Zur Vervollkommnung der quantitativen Phytoplankton Mitteilungen. Internationale Vereiningung fuer Theoretische und Angewandte Limnologie 9, 1-39.

van Iperen, J.M., Van Weering, T.C.E., Jansen, J.H.F., Van Bennekom, A.J. 1987. Diatoms in surface sediments of the Zaire deep-sea fan (SE Atlantic Ocean) and their relation to overlying water masses. Netherlands Journal of Sea Research 21, 203-217.

Varela, M., Prego, R., 2003. Hydrography and phytoplankton in an isolated and non-pristine ria area: the A Coruña Harbour (NW Spain). Acta Oecologica 24, 113-124

Varela, M., Prego, R., Belzunce, M.J., Martín-Salas, F., 2001. Inshore-offshore differences in seasonal variations of phytoplankton assemblages: the case of a Galician Ria Alta (A Coruña Ria) and its adjacent shelf (NW Spain). Continental Shelf Research 21, 18151838.

Varela, M., Prego, R., Pazos, Y., 2004. Vertical biogenic particle flux in a western Galician ria (NW Iberian Peninsula). Marine Ecology Progress Series 269, 17-32.

Varela, M., Prego, R., Pazos, Y., Moroño, A., 2005. Influence of upwelling and river runoff interaction on phytoplankton assemblages in a Middle Galician Ria and comparison with northern and southern rias (NW Iberian Peninsula). Estuarine, Coastal and Shelf Science 64, 721-737.

Varela, M.M., Bode, A., González, N., Rodríguez, C., Varela, M., 2003. Fate of organic matter in the Ría de Ferrol (Galicia, NW Spain): uptake by pelagic bacteria vs. particle sedimentation. Acta Oecologica 24, S77-S86. 


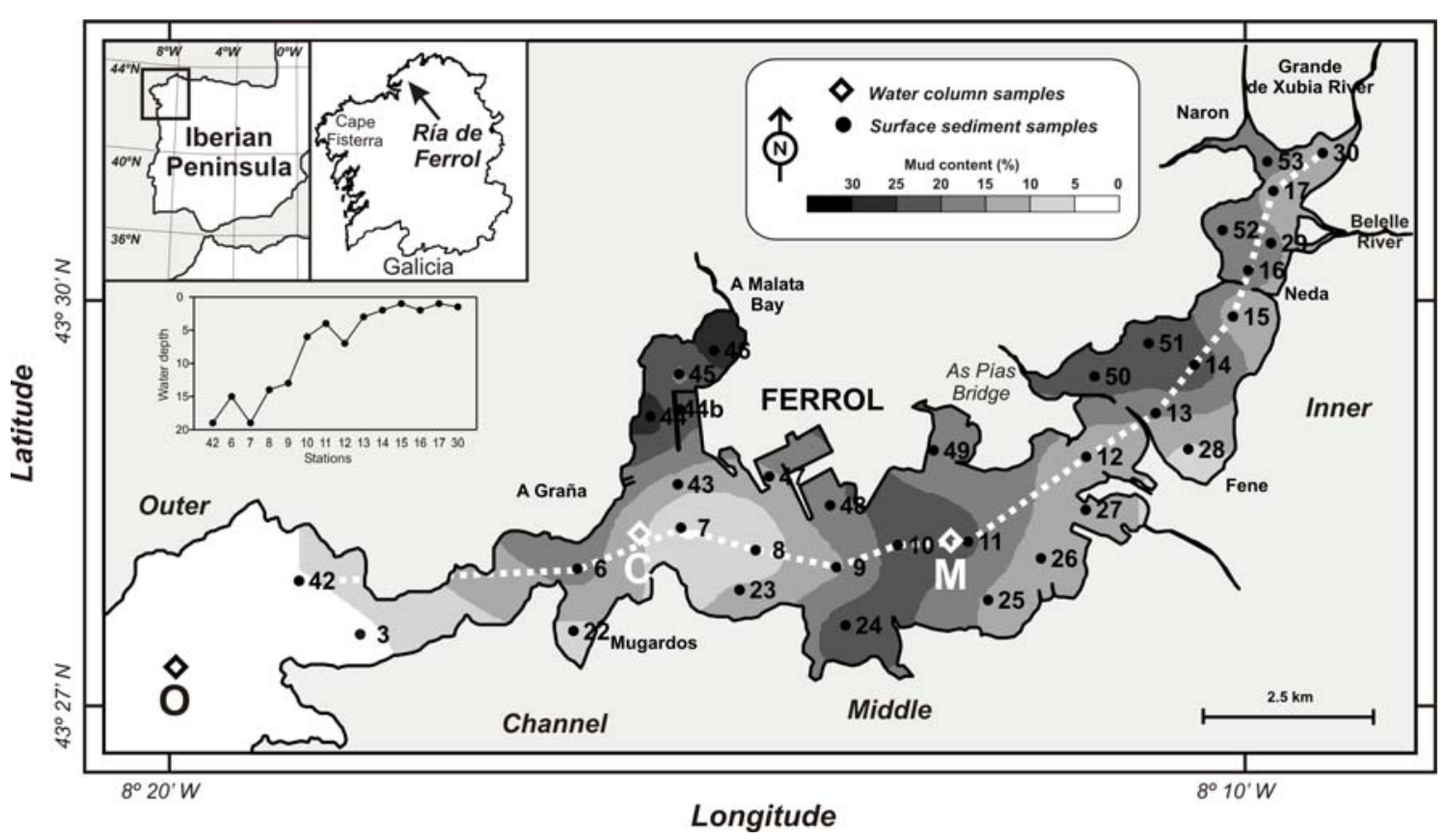

Figure 1. Map of the study area. The position of the bed sediment sampling (black circles) is shown. The diamond shapes indicate the stations where the water column phytoplankton sampling was carried out. The contour plot shows the mud content in the surface sediments (modified from Cobelo-García and Prego (2004). The dotted white line represents the longitudinal axis. Water depth variation along the longitudinal axis of the ría is also shown.

10 


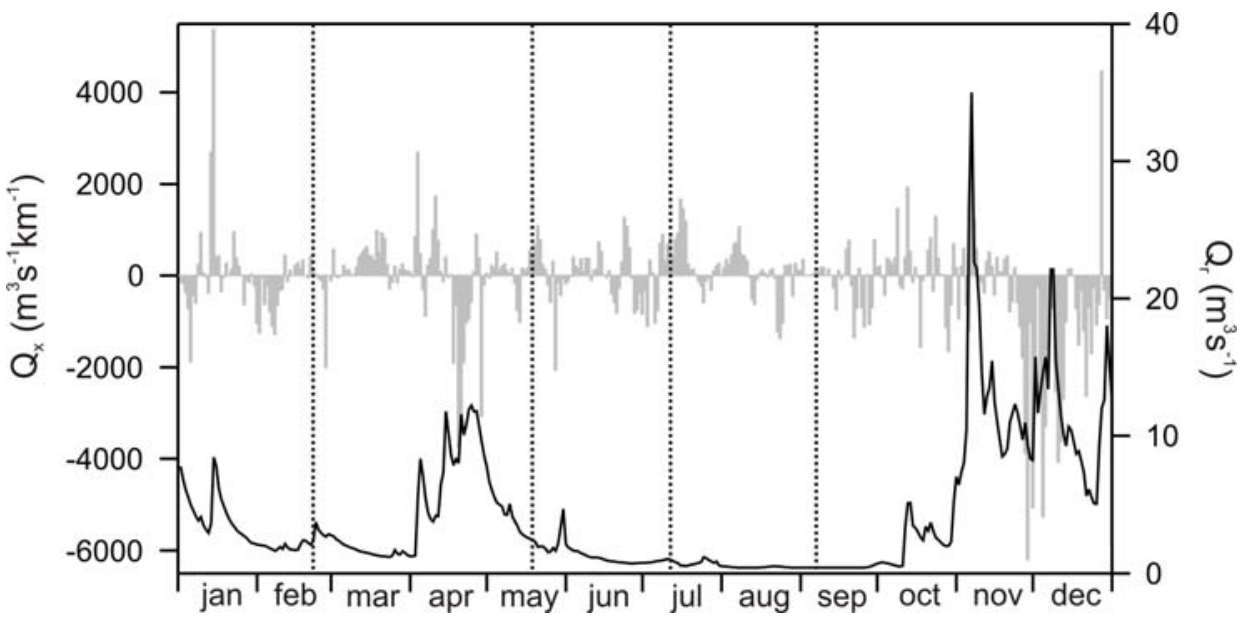

Figure 2. The solid line indicates the Grande de Xubia River daily discharge during the year 2000 (values in $\mathrm{m}^{3} \mathrm{~s}^{-1}$ ). Grey bars show the daily variations of the Upwelling index $\left(\mathrm{Q}_{x} \mathrm{~m}^{3} \mathrm{~s}^{-1} \mathrm{~km}^{-1}\right)$ at point $43^{\circ} 11^{\prime \prime}$ kindly provided by Jose Manuel Cabanas (IEO). Dashed lines indicate the water column sampling dates. 

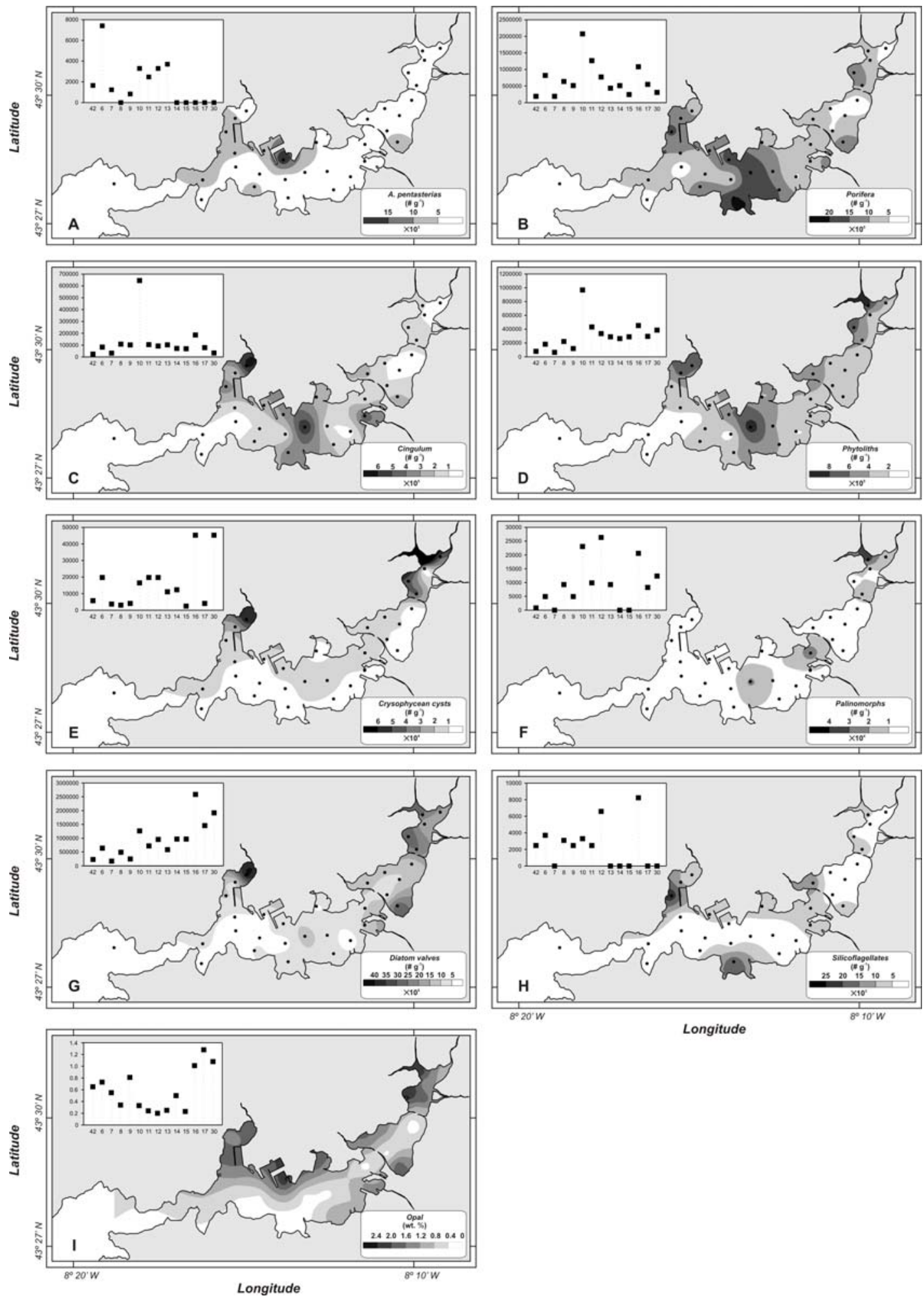

Figure 3. Contour plots of the abundance per gram of the sediment of different sediment components. Variation in the abundance of each componente along the longitudinal axis is also shown A) Actiniscus pentasterias, B) Porifera, C) Cingulum, D) Phytoliths, E) Crysophycean cysts, F) Palinomorphs, G) Diatom valves, H) Silicoflagellates, I) Opal content 

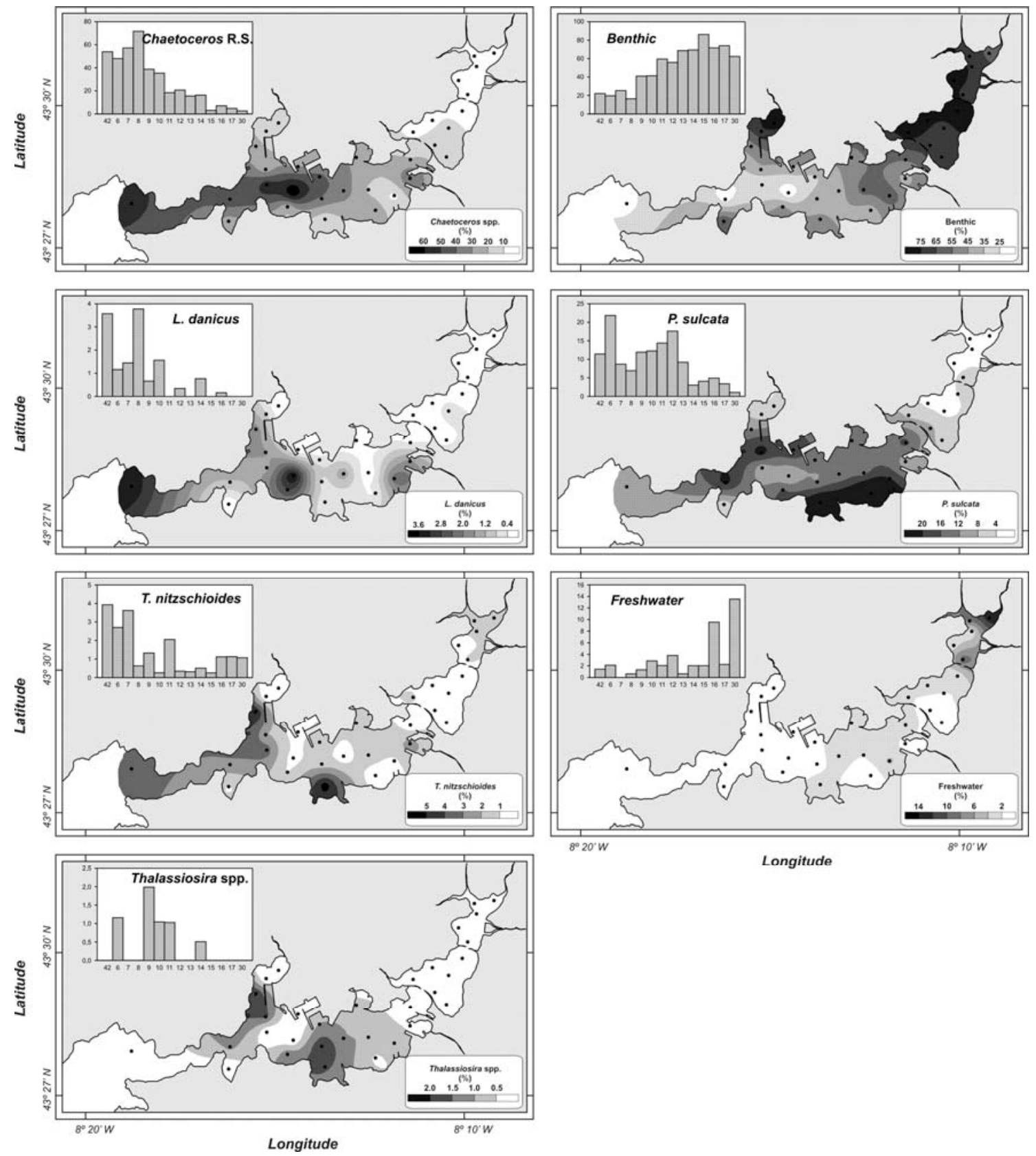

Figure 4. Maps showing the distribution of the main diatom species found in the surface sediment of the Ferrol Ría as well as the variation in their relative percentages along the longitudinal axis. 

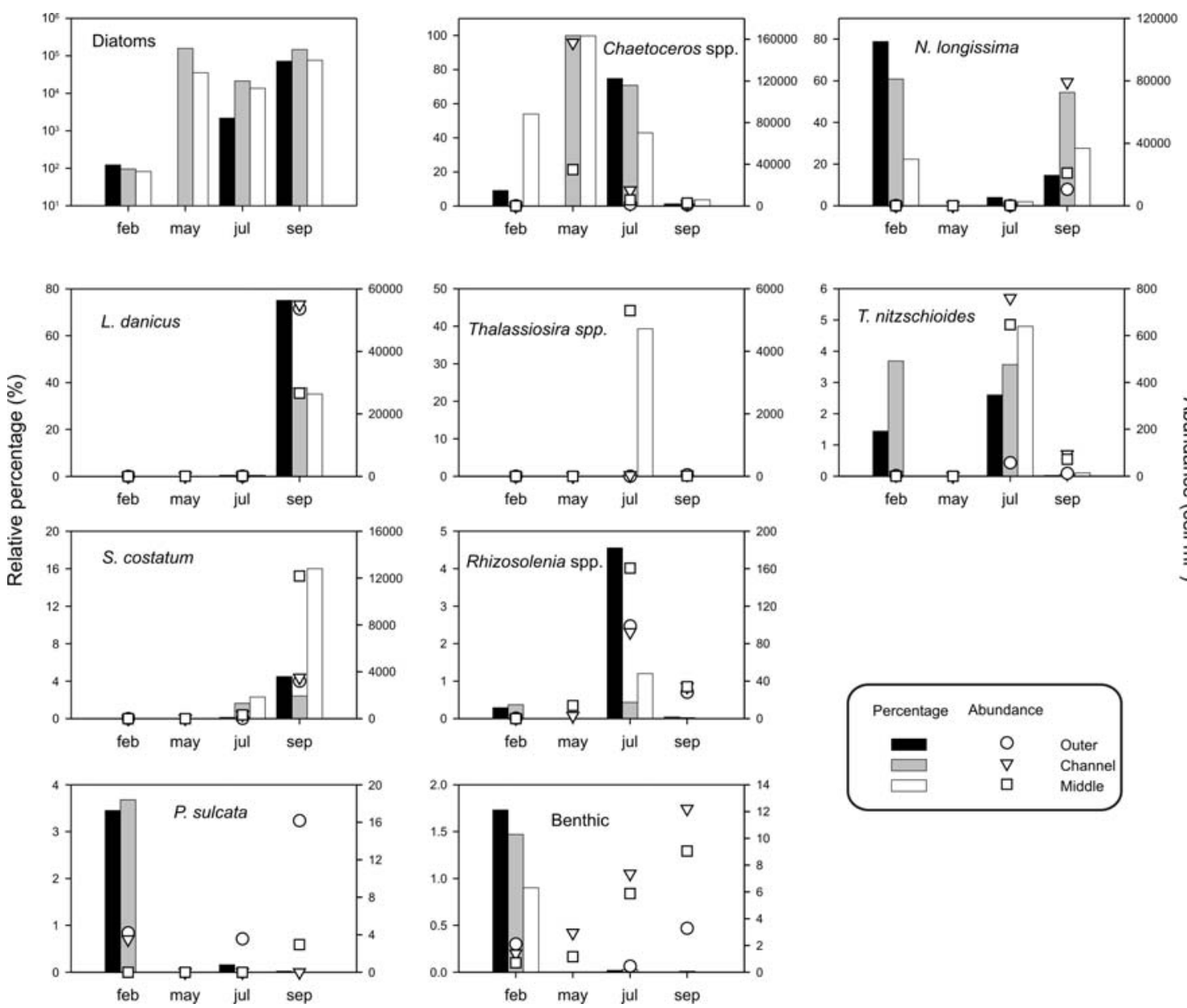

Figure 5. Temporal variations of the standing stocks of total diatoms and the abundance of the main diatom groups in the water column (white symbols, cell ml-1) at the three sampling sites. Bars show the relative percentage of each species or group. Note the logarithmic scale in the diagram showing the total diatom. Also note that there are no data for the outer station in the sampling survey for May. 


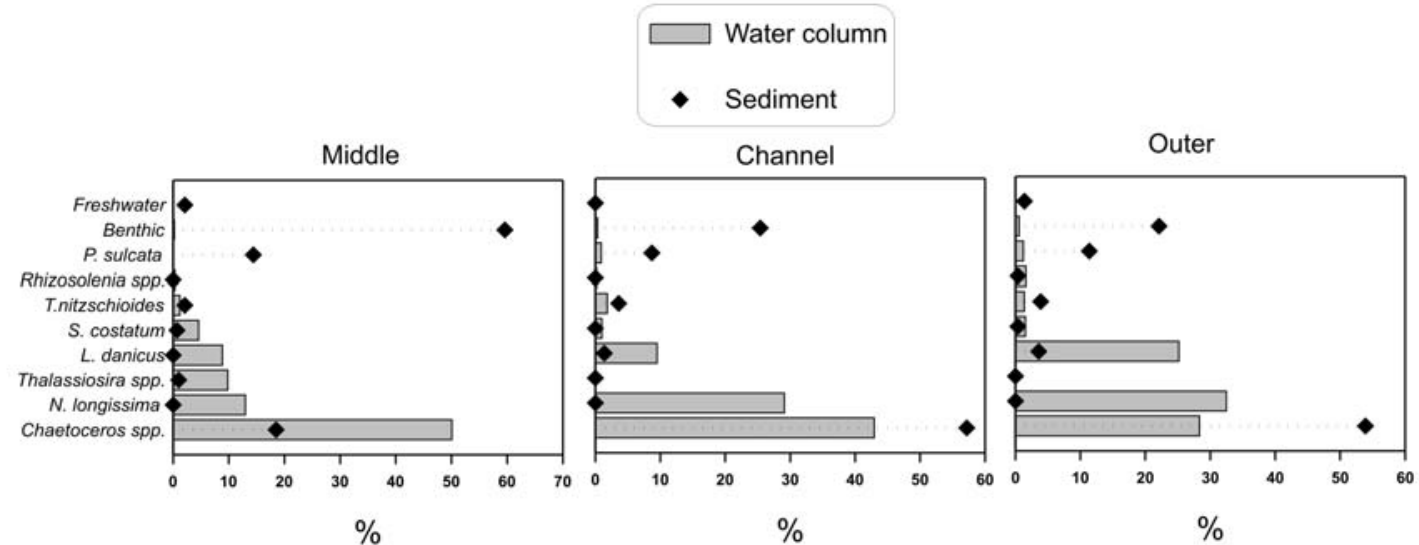

2 Figure 6. Mean value of the relative contribution of the diatom taxa in the water 4 column during the sampling period and percentage of diatoms accumulated in 5 surface sediment at sites 42 (Outer), 7 (Channel) and 11 (Middle). 
Table 1. Sediment characterization of the sampling sites.

\begin{tabular}{|c|c|c|c|c|c|c|c|c|c|c|}
\hline $\begin{array}{l}\text { Sediment } \\
\text { sample }\end{array}$ & Latitude $\mathbf{N}$ & Longitude W & Depth (m) & $\begin{array}{c}\text { Mud } \\
\text { (\%) }\end{array}$ & $\begin{array}{l}\text { POM } \\
\text { (\%) }\end{array}$ & $\begin{array}{c}\text { TOC } \\
\text { (\%) }\end{array}$ & $\begin{array}{l}\text { TON } \\
\text { (\%) }\end{array}$ & $\begin{array}{l}\text { Opal } \\
\text { (\%) }\end{array}$ & $\begin{array}{c}\mathrm{CaCO}_{3} \\
(\%)\end{array}$ & $\mathrm{C} / \mathrm{N}$ \\
\hline 3 & $43^{\circ} 27.465^{\prime}$ & $8^{\circ} 18.221^{\prime}$ & 15 & 3.97 & 5.80 & 0.84 & 0.1 & 0.04 & 72.14 & 8.40 \\
\hline 6 & $43^{\circ} 28.364^{\prime}$ & $8^{\circ} 15.457$ & 15 & 17.88 & 11.20 & 2.7 & 0.18 & 0.73 & 30.82 & 15.00 \\
\hline 7 & $43^{\circ} 28.183^{\prime}$ & $8^{\circ} 14.768^{\prime}$ & 19 & 4.26 & 7.90 & 1.63 & 0.09 & 0.55 & 35.99 & 18.11 \\
\hline 8 & $43^{\circ} 28.189^{\prime}$ & $8^{\circ} 14.391$ & 14 & 4.91 & 12.50 & 4.65 & 0.18 & 0.34 & 43.82 & 25.83 \\
\hline 9 & $43^{\circ} 28.163^{\prime}$ & $8^{\circ} 13.618^{\prime}$ & 13 & 13.72 & 13.50 & 2.94 & 0.24 & 0.81 & 23.49 & 12.25 \\
\hline 10 & $43^{\circ} 28.222^{\prime}$ & $8^{\circ} 12.725^{\prime}$ & 6 & 21.73 & 15.70 & 3.5 & 0.39 & 0.33 & 8.66 & 8.97 \\
\hline 11 & $43^{\circ} 28.427^{\prime}$ & $8^{\circ} 12.083^{\prime}$ & 4 & 21.72 & 12.10 & 3.01 & 0.24 & 0.24 & 8.33 & 12.54 \\
\hline 12 & $43^{\circ} 28.687^{\prime}$ & $8^{\circ} 11.368^{\prime}$ & 7 & 10.02 & 10.70 & 2.24 & 0.17 & 0.20 & 19.99 & 13.18 \\
\hline 13 & $43^{\circ} 28.854^{\prime}$ & $8^{\circ} 10.698^{\prime}$ & 3 & 15.61 & 9.70 & 2.34 & 0.14 & 0.25 & 24.66 & 16.71 \\
\hline 14 & $43^{\circ} 29.71^{\prime}$ & $8^{\circ} 10.432$ & 2 & 25.60 & 9.80 & 2.28 & 0.23 & 0.50 & 3.67 & 9.91 \\
\hline 15 & $43^{\circ} 29.84^{\prime}$ & $8^{\circ} 10.123^{\prime}$ & 1 & 11.63 & 11.10 & 2.32 & 0.2 & 0.23 & 17.16 & 11.60 \\
\hline 16 & $43^{\circ} 30.23^{\prime}$ & $8^{\circ} 10.02^{\prime}$ & 2 & 17.83 & 18.10 & 3.93 & 0.47 & 1.01 & 8.66 & 8.36 \\
\hline 17 & $43^{\circ} 30.83^{\prime}$ & $8^{\circ} 09.902$ & 1 & 12.66 & 17.30 & 4.01 & 0.45 & 1.28 & 6.83 & 8.91 \\
\hline 22 & $43^{\circ} 27.703^{\prime}$ & $8^{\circ} 15.802^{\prime}$ & 9 & 8.37 & 6.60 & 1.07 & 0.07 & 0.42 & 28.32 & 15.29 \\
\hline 23 & $43^{\circ} 27.76^{\prime}$ & $8^{\circ} 14.558^{\prime}$ & 6 & 11.41 & 9.90 & 2.04 & 0.14 & 0.25 & 25.16 & 14.57 \\
\hline 24 & $43^{\circ} 27.745^{\prime}$ & $8^{\circ} 13.504$ & 4 & 23.98 & 12.50 & 2.44 & 0.21 & 0.07 & 20.83 & 11.62 \\
\hline 25 & $43^{\circ} 28.033^{\prime}$ & $8^{\circ} 12.594^{\prime}$ & 4 & 13.92 & 15.20 & 3.93 & 0.26 & 1.13 & 15.99 & 15.12 \\
\hline 26 & $43^{\circ} 28.222^{\prime}$ & $8^{\circ} 11.83^{\prime}$ & 3 & 12.08 & 11.80 & 2.32 & 0.24 & 0.78 & 13.49 & 9.67 \\
\hline 27 & $43^{\circ} 28.34^{\prime}$ & $8^{\circ} 11.423^{\prime}$ & 4 & 13.83 & 14.40 & 2.51 & 0.3 & 1.28 & 12.00 & 8.37 \\
\hline 28 & $43^{\circ} 28.653^{\prime}$ & $8^{\circ} 10.487^{\prime}$ & 2 & 8.99 & 18.40 & 3.71 & 0.51 & 1.86 & 9.50 & 7.27 \\
\hline 29 & $43^{\circ} 30.521^{\prime}$ & $8^{\circ} 09.802^{\prime}$ & 2.5 & 15.90 & 22.40 & 5.92 & 0.63 & 1.83 & 6.50 & 9.40 \\
\hline 30 & $43^{\circ} 31.12^{\prime}$ & $8^{\circ} 09.43^{\prime}$ & 1.5 & 13.55 & 8.30 & 2.19 & 0.2 & 1.08 & 2.50 & 10.95 \\
\hline 42 & $43^{\circ} 27.973^{\prime}$ & $8^{\circ} 19.038^{\prime}$ & 19 & 4.41 & 5.50 & 0.71 & 0.06 & 0.65 & 29.99 & 11.83 \\
\hline 43 & $43^{\circ} 28.643^{\prime}$ & $8^{\circ} 15.139$ & 14 & 12.31 & 12.70 & 4.25 & 0.2 & 1.33 & 30.99 & 21.25 \\
\hline 44 & $43^{\circ} 28.864^{\prime}$ & $8^{\circ} 15.359^{\prime}$ & 5 & 28.93 & 14.50 & 3.01 & 0.3 & 1.83 & 10.83 & 10.03 \\
\hline 45 & $43^{\circ} 29.52^{\prime}$ & $8^{\circ} 15.139^{\prime}$ & 2 & 18.10 & 13.30 & 3.91 & 0.26 & 1.42 & 11.33 & 15.04 \\
\hline
\end{tabular}




\begin{tabular}{ccccccccccc}
46 & $43^{\circ} 29.831^{\prime}$ & $8^{\circ} 15.034^{\prime}$ & 1 & 28.14 & 13.10 & 2.29 & 0.32 & 1.81 & 6.50 & 7.16 \\
47 & $43^{\circ} 28.471^{\prime}$ & $8^{\circ} 14.23^{\prime}$ & 8 & 14.00 & 12.70 & 3.01 & 0.2 & 1.52 & 22.32 & 15.05 \\
48 & $43^{\circ} 28.496^{\prime}$ & $8^{\circ} 13.824^{\prime}$ & 9 & 19.64 & 14.80 & 2.93 & 0.33 & 2.23 & 13.66 & 8.88 \\
49 & $43^{\circ} 28.663^{\prime}$ & $8^{\circ} 12.77^{\prime}$ & 4 & 17.79 & 13.80 & 2.79 & 0.29 & 1.83 & 11.50 & 9.62 \\
50 & $43^{\circ} 29.42^{\prime}$ & $8^{\circ} 11.121^{\prime}$ & 1 & 23.89 & 11.20 & 2.12 & 0.27 & 1.53 & 7.16 & 7.85 \\
51 & $43^{\circ} 29.781^{\prime}$ & $8^{\circ} 10.751^{\prime}$ & 1 & 23.63 & 9.10 & 1.69 & 0.17 & 1.31 & 9.50 & 9.94 \\
52 & $43^{\circ} 30.621^{\prime}$ & $8^{\circ} 10.223^{\prime}$ & 1.5 & 19.08 & 19.60 & 4.59 & 0.54 & 2.34 & 7.50 & 8.50 \\
53 & $43^{\circ} 31.02^{\prime}$ & $8^{\circ} 09.982^{\prime}$ & 1 & 17.67 & 17.70 & 3.89 & 0.45 & 2.12 & 7.16 & 8.64 \\
$44 \mathrm{~b}$ & $43^{\circ} 28.931^{\prime}$ & $8^{\circ} 15.06^{\prime}$ & 7 & 22.36 & 14.70 & 3.23 & 0.29 & 1.83 & 11.50 & 11.14 \\
\hline Max & & & & 28.93 & 22.4 & 5.92 & 0.63 & 2.34 & 72.14 & 25.83 \\
Min & & & & 3.97 & 5.5 & 0.71 & 0.06 & 0.04 & 2.5 & 7.16 \\
Mean & & & & 15.81 & 12.79 & 2.88 & 0.27 & 1.06 & 17.67 & 11.91 \\
\hline
\end{tabular}




\begin{tabular}{|c|c|c|c|c|}
\hline Benthic group & M & $\mathrm{C}$ & $\mathrm{O}$ & Sediment \\
\hline Achnanthes spp. Bory 1822 & & & & $\mathrm{X}$ \\
\hline Amphora spp. (Ehrenberg) Kützing 1844 & & & & $x$ \\
\hline Auliscus sculptus (Smith) Ralfs in Pritchard 1864 & & & & $\mathrm{x}$ \\
\hline Campylodiscus spp. Ehrenberg ex Kützing 1844 & & & & $x$ \\
\hline Cerataulus turgidus Ehrenberg 1843 & & & & $x$ \\
\hline Cocconeis spp. Ehrenberg 1837 & & & & $x$ \\
\hline Cocconeis distans Gregory 1855 & & & & $x$ \\
\hline Cocconeis placentula Ehrenberg 1838 & & & & $x$ \\
\hline Cocconeis scutellum Ehrenberg 1838 & $\mathrm{x}$ & $\mathrm{x}$ & & $\mathrm{x}$ \\
\hline Dimeregramma minor (Gregory) Ralfs in Pritchard 1861 & & & & $x$ \\
\hline Diploneis spp. (Ehrenberg) Cleve 1894 & & & & $x$ \\
\hline Diploneis bombus (Ehrenberg) Ehrenberg ex Cleve 1894 & & & & $x$ \\
\hline Diploneis didyma (Ehrenberg) Cleve 1894 & & & & $x$ \\
\hline Diploneis smithii (Brébisson ex Smith) Cleve 1894 & & & & $x$ \\
\hline Grammatophora angulosa Ehrenberg 1840 & & & & $x$ \\
\hline Grammatophora spp. Ehrenberg 1840 & & & & $x$ \\
\hline Grammatophora marina (Lyngbye) Kützing 1844 & & $x$ & & $x$ \\
\hline Grammatophora serpentina (Ralfs) Ehrenberg 1844 & & & & $x$ \\
\hline Gyrosigma spp. Hassall 1845 & $x$ & & & $x$ \\
\hline Hantzschia spp. Grunow 1877 & & & & $x$ \\
\hline Navicula spp. Bory 1822 & & & & $x$ \\
\hline Navicula digitoradiata (Gregory) Ralfs in Pritchard 1861 & & & & $x$ \\
\hline Navicula distans (Smith) Ralfs in Pritchard 1861 & & & & $x$ \\
\hline Navicula forcipata Greville 1859 & & & & $x$ \\
\hline Navicula palpebralis (de Brébisson) Smith 1853 & & & & $x$ \\
\hline Navicula transitrans (Grunow) Cleve 1883 & & $\mathrm{x}$ & $x$ & \\
\hline Opephora spp. Petit 1888 & & & & $x$ \\
\hline Petroneis monilifera (Gregory) Stickle \& Mann 1990 & & & & $x$ \\
\hline Plagiogramma staurophorum (Gregory) Heiberg 1863 & & & & $x$ \\
\hline Pleurosigma acutum Norman ex Ralfs in Pritchard 1861 & & & $x$ & \\
\hline
\end{tabular}


Pleurosigma spp. Smith 1852

Podosira stelligera (Bailey) Mann 1907

Psammodiscus nitidus (Gregory) Round and Mann 1990

Rhabdonema minutum Kützing 1844

Surirella fastuosa (Ehrenberg) Kützing 1844

Toxarium spp. Bailey 1854

Trachyneis aspera (Ehrenberg) Cleve 1894

Trachyneis spp. Cleve 1894

Tryblionella Smith (1853)

Tryblionella coarctata (Grunow) Mann in Round et al., 1990

Tryblionella punctata Smith 1853

$x$
$x$
$x$
$x$
$x$
$x$
$x$
$x$
$x$
$x$

Freshwater group

M

C

$\mathrm{O}$

Sediment

Achnanthes lanceolata (de Brébisson in Kützing) Grunow in Cleve et Grunow 1880

Achnanthes minutissima Kützing 1933

Aulacoseria spp. Thwaites 1848

Aulacoseria granulata (Ehrenberg) Ralfs in Pritchard 1861

Cyclotella spp. (Kützing) de Brébisson 1838

Cymbella spp. Agardh 1830

Diatoma spp. Bory 1824

Diatoma hyemalis (Roth) Heiberg 1863

Eunotia spp. Ehrenberg 1837

Eunotia pectinalis (O.F. Müller) Rabenhorst, 1864

Fragillaria spp. Lyngbye 1819

Gomphonema spp. Ehrenberg 1832

Gomphonema acuminatum Ehrenberg 1832

Hannaea arcus (Ehrenberg) Patrick 1966

Pinnularia spp. Ehrenberg 1843

Sellaphora spp. Mereschkowsky 1902

Staurosirella spp. Williams and Round 1988

Staurosirella pinnata (Ehrenberg) Williams and Round 1987

Stephanodiscus spp. Ehrenberg 1845

Synedra spp. Ehrenberg 1830

Synedra ulna (Nietzsche) Ehrenberg 1838 
Tabellaria spp. Ehrenberg 1840

\begin{tabular}{|c|c|c|c|c|}
\hline Other species & M & $\mathrm{C}$ & $\mathrm{O}$ & Sediment \\
\hline Actinoptychus senarius (Ehrenberg) Ehrenberg 1843 & & & & $\mathrm{x}$ \\
\hline Actinoptychus splendens (Shadbolt) Ralfs ex Pritchard 1861 & & & & $x$ \\
\hline Anaulus spp. Ehrenberg 1844 & & & & $x$ \\
\hline Asterionellopsis glacialis (Castracane) Round in Round et al., 1990 & $x$ & $x$ & $x$ & \\
\hline Bacteriastrum spp. Shadbolt 1854 & & $x$ & & \\
\hline Bacteriastrum delicatulum Cleve 1897 & $x$ & $x$ & & \\
\hline Bacteriastrum hyalinum Lauder 1864 & $x$ & $x$ & $x$ & \\
\hline Biddulphia alternans (J.W. Bailey) Van Heurck 1885 & & & & $x$ \\
\hline Biddulphia obtusa (Kützing) Ralfs in Pritchard 1861 & & & & $x$ \\
\hline Cerataulina pelagica (Cleve) Hendey 1937 & $x$ & $x$ & & \\
\hline Chaetoceros spp. Ehrenberg 1844 & $x$ & & $x$ & \\
\hline Chaetoceros spp. R.S. Ehrenberg 1844 & $x$ & & $x$ & $x$ \\
\hline Chaetoceros affinis Lauder 1864 & $x$ & & $x$ & $x$ \\
\hline Chaetoceros brevis Schütt 1895 & $x$ & $x$ & $x$ & \\
\hline Chaetoceros curvisetus Cleve 1889 & $x$ & $x$ & $x$ & \\
\hline Chaetoceros danicus Cleve 1889 & $x$ & $x$ & $x$ & \\
\hline Chaetoceros decipiens Cleve 1873 & $x$ & $x$ & $x$ & \\
\hline Chaetoceros densus Cleve 1901 & $x$ & $x$ & & \\
\hline Chaetoceros diadema (Ehrenberg) Gran 1897 & & & & $x$ \\
\hline Chaetoceros didymus Ehrenberg 1845 & $x$ & $x$ & $x$ & \\
\hline Chaetoceros lauderi Ralfs in Lauder 1864 & $x$ & & & \\
\hline Chaetoceros Iorenzianus Grunow 1863 & & $x$ & & \\
\hline Chaetoceros simplex Ostenfeld 1901 & & & $x$ & \\
\hline Chaetoceros socialis Lauder 1864 & $x$ & $x$ & $x$ & \\
\hline Coscinodiscus spp. (Ehrenberg) Hasle and Sims 1986 & $x$ & $x$ & $x$ & $x$ \\
\hline Coscinodiscus argus Ehrenberg 1838 & & & & $x$ \\
\hline Coscinodiscus decrescens Grunow in Schmidt 1878 & & & & $x$ \\
\hline Coscinodiscus radiatus Ehrenberg 1841 & & & & $x$ \\
\hline Detonula pumila (Castracane) Schütt 1896 & $x$ & $x$ & $x$ & \\
\hline Eucampia zodiacus Ehrenberg 1840 & $x$ & $x$ & & \\
\hline Guinardia delicatula (Cleve) Hasle 1996 & $x$ & $x$ & $x$ & \\
\hline
\end{tabular}


Guinardia flaccida (Castracane) Peragallo 1892

Guinardia striata (Stoltherfoth) Hasle1996

Hemidiscus cuneiformis Wall 1860

Lauderia annulata Cleve 1873

Leptocylindrus danicus Cleve 1889

Leptocylindrus danicus R.S. Cleve 1889

Leptocylindrus minimus Gran 1915

Lioloma pacificum (Cupp) Hasle 1996

Nitzschia spp. Hassall 1845

Nitzschia bicapitata Cleve 1901

Nitzschia longissima (de Brébisson in Kützing) Ralfs in Pritchard 1861

Odontella mobiliensis (Bailey) Grunow 1884

Paralia sulcata (Ehrenberg) Cleve 1873

Proboscia alata (Brightwell) Sundström 1986

Pseudonitzschia spp. Peragallo in Peragallo 1900

Pseudonitzschia cf. pungens (Grunow ex Cleve) Hasle 1993

Pseudonitzschia subpacifica (Hasle) Hasle 1993

Pseudonitzschia cf. delicatissima (Cleve) Heiden in Heiden and Kolbe

1928

Rhizosolenia spp. Brightwell 1858

Rhizosolenia setigera Brightwell 1858

Rhizosolenia shrubsolei Cleve 1881

Skeletonema costatum (Greville) Cleve 1878

Stephanopyxis turris (Greville and Arnott) Ralfs ex Pritchard 1861

Thalassionema nitzschioides (Grunow) Mereschkowsky 1902

Thalassionema frauenfeldii (Grunow) Hallegraeff 1986

Thalassiosira spp. (Cleve) Hasle 1973

Thalassiosira angulata (Gregory) Hasle 1978

Thalassiosira anguste-lineata (Schmidt) Fryxell et Hasle 1977

Thalassiosira fallax Meunier 1910

Thalassiosira levanderi Van Goor 1924

Thalassiosira rotula Meunier 1910

$x \quad x$

